\title{
Salivary Cortisol Reactivity in Preterm Infants in Neonatal Intensive Care: An Integrative Review
}

\author{
Evalotte Mörelius $^{1, *}$, Hong-Gu He ${ }^{2}$ and Shefaly Shorey ${ }^{2}$ \\ 1 Department of Social and Welfare Studies, Division of Nursing Science, Linköping University, \\ Norrköping 60174, Sweden \\ 2 Alice Lee Centre for Nursing Studies, Yong Loo Lin School of Medicine, National University Health System, \\ National University of Singapore, Singapore 119077, Singapore; nurhhg@nus.edu.sg (H-G.H.); \\ nurssh@nus.edu.sg (S.S.) \\ * Correspondence: evalotte.morelius@liu.se; Tel.: +46-1136-3556
}

Academic Editors: Catherine Bielajew and Guergana Mileva

Received: 12 January 2016; Accepted: 14 March 2016; Published: 18 March 2016

\begin{abstract}
Recently, more and more researchers have been using salivary cortisol reactivity to evaluate stress in preterm infants in the neonatal intensive care unit (NICU). The aim of this integrative literature review was to summarize the evidence of interventions leading to a change in salivary cortisol from the baseline in preterm infants in the NICU. The electronic databases of PubMed, CINAHL, Web of Science, and Scopus were searched for relevant studies. The inclusion criteria were studies with preterm infants exposed to an intervention evaluated by salivary cortisol reactivity before discharge from the NICU, which were published in English. In total, 16 studies were included. Eye-screening examination and heel lance provoked an increase in the salivary cortisol level. Music, prone position, and co-bedding among twins decreased the salivary cortisol level. Several studies reported a low rate of successful saliva sampling or did not use control groups. Future studies need to focus on non-painful interventions in order to learn more about salivary cortisol regulation in preterm infants. Moreover, these studies should use study designs comprising homogenous gestational and postnatal age groups, control groups, and reliable analysis methods that are able to detect cortisol in small amounts of saliva.
\end{abstract}

Keywords: cortisol; infants; neonatal care; nursing; pain; preterm; saliva; stress

\section{Introduction}

The hypothalamic-pituitary-adrenal (HPA) axis regulates cortisol production and the organism's capacity to respond to stressors and thus maintain homeostasis. From the beginning of the second trimester, the HPA axis functions and organizes in response to the environment [1-3]. Secretion of the cortisol is essential for lung maturation at birth, hence, there is a corresponding increase in cortisol levels with increasing gestational age [4-6]. One month after birth, full-term healthy infants develop a circadian rhythm of salivary cortisol with increasing morning levels and corresponding decreasing evening levels [7]. In preterm infants, developmental immaturity and/or the effects of critical illness on adrenal function may result in insufficient cortisol production to maintain homeostasis when exposed to a stressor [8,9]. Thus, preterm infants may be able to produce enough cortisol to maintain homeostasis under non-stressful conditions, but insufficient cortisol to respond appropriately when exposed to a stressor. An appropriate cortisol release in the face of a stressor is vital for survival and the lack of such a response increases the risk of morbidity and mortality in preterm infants [1]. On the other hand, longstanding high levels of cortisol may increase the risk of cognitive and behavioral problems, high blood pressure, and development of the metabolic syndrome [10-14]. 
The life of the preterm infant is inherently stressful from the moment of birth as the environment in a NICU is usually busy. Several infants are cared for in the same room; sounds and alarms from cardio respiratory monitors, incubators, and mechanical ventilators add to their stress. As a part of their medical care, the preterm infants are not only subjected to many different invasive procedures but also bombarded with stimuli from daily handling procedures (for instance: diaper changing, repositioning, weighing, and personal hygiene care). In a Canadian observational study, Johnston and colleagues found that preterm infants were subjected to a mean of six tissue-damaging and 14 non-tissue-damaging procedures in one week [15]. Grunau and colleagues have shown that children born very preterm exhibit altered HPA axis functioning at three, eight, and 18 months, and at seven years $[16,17]$. Moreover, they found that elevated salivary cortisol levels in eight and 18-month old preterm infants positively correlated to the amount of pain exposure in the neonatal period [18-20]. Compared to full-term infants, preterm infants are at greater risk of short-term consequences of stress (e.g., fluctuations in intracranial blood pressure with an increasing risk for intraventricular hemorrhage [21,22]), as well as long-term consequences of stress (e.g., allostatic load and an inability to respond appropriately to a stressor [23]).

In a review from 2009, it was found that infants aged under three months showed increased cortisol levels from baseline in response to painful interventions (e.g., heel lance and inoculation) as well as routine handling interventions (e.g., physical examination, diaper changing and removal from bath) [24]. Several studies indicated that in relation to routine handling interventions, preterm infants had symptoms of stress such as increased heart rate, skin conductance, and pain scores, and decreased oxygen saturation [25-29]. Pleasant interventions such as getting a massage and listening to recorded sounds of the maternal heartbeat have been shown to decrease salivary cortisol levels in full-term infants [30,31]. A combination of sweet-tasting oral solution and pacifier as pain relief during vaccination has also been shown to decrease salivary cortisol levels in full-term infants [32], as has non-nutritive sucking during circumcision [33]. Moreover, practicing neonatal care methods such as family-centered care, skin-to-skin contact (SSC) and holding have been proved to have a beneficial impact on the developing HPA axis in preterm infants [34-36]. However, no review has summarized preterm infants' cortisol reactivity in response to painful, handling and pleasant interventions, respectively.

Mode of delivery and prenatal exposure to maternal stress have also been shown to affect the subsequent cortisol reactivity of the infant [37-39]. For example, Taylor and colleagues found a lower cortisol reactivity during a four-month-vaccination among infants delivered by cesarean-section compared to vaginally-born infants [37]. Similarly, O'Connor and collaborators found lower cortisol reactivity during stress provocation (Ainsworth's strange situation) in 17-month-old infants who were exposed to high levels of cortisol in utero [39].

It is important to know what stressors are suitable to use to evaluate salivary cortisol reactivity in preterm infants in order to guide researchers in future studies. Available reviews were focused on salivary cortisol reactivity in response to acute stressors in adults [40] and children [24,41]. Cortisol in saliva has been used as a valid method to measure adrenocortical activity in newborns since 1987 [42]; however, no reviews have been conducted to summarize the salivary cortisol reactivity in relation to acute stressors in preterm infants in the NICU. Moreover, it is important to evaluate the type of interventions performed in the NICU that are beneficial for preterm infants in order to prevent longstanding high levels of cortisol and allostatic load.

The aim of this review was to summarize the evidence from interventions leading to a change in salivary cortisol levels from the baseline (before the intervention) to response (after the intervention) in preterm infants in the NICU. The specific research questions were:

- What interventions lead to an increase in salivary cortisol levels from the baseline to response in preterm infants in the NICU?

- What interventions lead to a decrease in salivary cortisol levels from the baseline to response in preterm infants in the NICU? 


\section{Materials and Methods}

\subsection{Design}

This was an integrative literature review, which provided a summary of the interventions leading to either an increase or decrease in salivary cortisol levels from the baseline in preterm infants in the NICU.

\subsection{Study Selection}

The inclusion criteria were studies with preterm infants exposed to an intervention evaluated by salivary cortisol reactivity (baseline and response values) in the NICU. Studies without an intervention or studies using adrenocorticotropic hormone (ACTH) stimulation, studies with only baseline or only response values presented, and successful saliva sampling $\leqslant 50 \%$ were excluded. Studies using citric acid as a saliva stimulant were also excluded since this is known to interfere with the cortisol levels by lowering the sample $\mathrm{PH}[43]$.

\subsection{Search Strategy}

Four electronic databases (PubMed, CINAHL, Web of Science, and Scopus) were used to search for relevant studies. The search terms used were cortisol, infant, saliva/salivary, and preterm/premature. Limits were set to English and human, and no limit was set for years. The search took place in September 2015.

The database search resulted in 177 articles. Additional studies were also identified through other sources e.g., reference lists $(n=5)$. Abstracts were reviewed $(n=82)$ and all articles that could not be conclusively excluded based on the abstract were retrieved to determine eligibility. After full-text reading $(n=26), 10$ articles were excluded due to the exclusion criteria (Figure 1). Eventually, 16 studies were included in this review (Table 1 ).
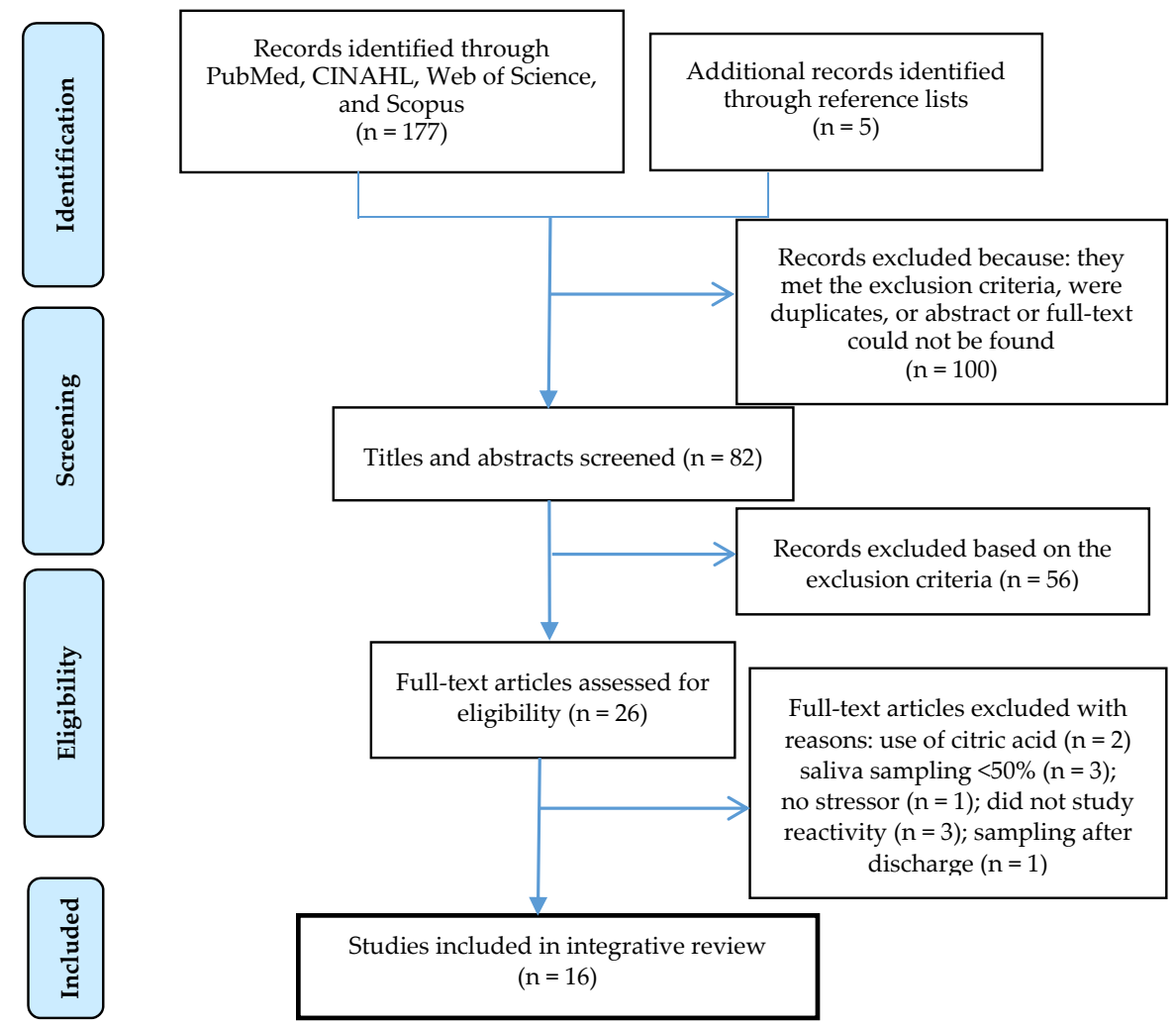

Figure 1. PRISMA flow diagram on the outcomes of the search strategies. 
Table 1. Descriptive data of included studies $(n=16)$

\begin{tabular}{|c|c|c|c|c|c|c|c|c|c|c|c|c|}
\hline Author Year Country & GA Age $^{+}$ & $\begin{array}{l}\text { Post-Natal } \\
\text { Age, Days }\end{array}$ & Design & Study Groups & $n$ & Intervention & $\begin{array}{c}\text { Sampling } \\
\text { Times }\end{array}$ & $\begin{array}{l}\text { Successful Saliva } \\
\text { Sampling }\end{array}$ & $\begin{array}{c}\text { Storage } \\
\text { Temperature }\left({ }^{\circ} \mathrm{C}\right)\end{array}$ & $\begin{array}{l}\text { Analyze } \\
\text { Method }\end{array}$ & $\begin{array}{c}\text { Intra/Inter } \\
\mathrm{CV}\end{array}$ & $\begin{array}{c}\text { Cortisol } \\
\text { Response }\end{array}$ \\
\hline \multicolumn{13}{|l|}{ Painful } \\
\hline $\begin{array}{l}\text { Cignacco et al. } 2009 \\
\text { Switzerland [44] }\end{array}$ & $28-31$ & $<14$ & Single group & Sucrose & 9 & Heel lance & $-25,+30$ & $99 \%$ & Not stated & RIA & Not stated & $\begin{array}{c}\text { Not } \\
\text { significant }\end{array}$ \\
\hline $\begin{array}{l}\text { Cong et al. } 2011 \\
\text { USA [45] }\end{array}$ & $30-32$ & $2-9$ & $\begin{array}{l}\text { Randomized } \\
\text { crossover }\end{array}$ & $\begin{array}{l}\text { Incubator care } \\
\text { vs. SSC } 30 \mathrm{~min} \\
\text { or } 80 \mathrm{~min}\end{array}$ & $18+10$ & Heel lance & $0,+20$ & * & -70 & Not stated & $4.8 / 6.3$ & Not stated \\
\hline $\begin{array}{l}\text { Badiee et al. } 2013 \\
\text { Iran [46] }\end{array}$ & $32-37$ & $1-30$ & $\begin{array}{l}\text { Randomized } \\
\text { clinical study }\end{array}$ & $\begin{array}{l}\text { Formula odor } \\
\text { vs. breast } \\
\text { milk odor }\end{array}$ & $25+25$ & Heel lance & $0,+20$ & Not stated & Not stated & ELISA & Not stated & Not stated \\
\hline $\begin{array}{l}\text { Badiee et al. } 2014 \\
\text { Iran [47] }\end{array}$ & $26-34$ & $<20$ & $\begin{array}{l}\text { Randomized } \\
\text { clinical study }\end{array}$ & $\begin{array}{c}\text { Standard care } \\
\text { vs. Co-bedding }\end{array}$ & $50+50$ & Heel lance & $0,+20$ & Not stated & Not stated & ELISA & Not stated & Not stated \#\# \\
\hline $\begin{array}{l}\text { Campbell-Yeo et al. } 2014 \\
\text { Canada [48] }\end{array}$ & $28-36$ & $\begin{array}{l}\text { Mean } 12.0 \\
\text { and } 18.96\end{array}$ & $\begin{array}{l}\text { Randomized } \\
\text { clinical study }\end{array}$ & $\begin{array}{c}\text { Standard care } \\
\text { vs. Co-bedding }\end{array}$ & $62+72$ & Heel lance & $0,+20$ & $57 \%$ & -20 & EIA & $2.24 / 2.47$ & Decrease ${ }^{\# \#}$ \\
\hline $\begin{array}{l}\text { Kleberg et al. } 2008 \\
\text { Sweden [49] }\end{array}$ & $23-31$ & $<35$ & $\begin{array}{l}\text { Randomized } \\
\text { crossover }\end{array}$ & $\begin{array}{l}\text { Standard care } \\
v s . \text { NIDCAP }\end{array}$ & 36 & $\begin{array}{l}\text { Eye-screening } \\
\text { exam. }\end{array}$ & $\begin{array}{c}0,+30,+60 \\
+4 \mathrm{~h}\end{array}$ & $75 \%$ & -22 & RIA & $/ 6.0-12.0$ & Increase ${ }^{\#}$ \\
\hline $\begin{array}{l}\text { Ivars et al. } 2012 \\
\text { Sweden [50] }\end{array}$ & $27-33$ & $4-86$ & $\begin{array}{l}\text { Randomized } \\
\text { crossover }\end{array}$ & $\begin{array}{l}\text { Control vs. oral } \\
\text { glucose }\end{array}$ & 11 & $\begin{array}{l}\text { Nasopharyngeal } \\
\text { suctioning }\end{array}$ & $0,+30$ & $98 \%$ & -22 & RIA & $/ 6.0-12.0$ & $\begin{array}{c}\text { Not } \\
\text { significant }\end{array}$ \\
\hline $\begin{array}{l}\text { Boyer et al. } 2004 \\
\text { Canada [51] }\end{array}$ & $<31$ & $1-7$ & $\begin{array}{l}\text { Randomized } \\
\text { controlled } \\
\text { study }\end{array}$ & $\begin{array}{l}\text { Water vs. } \\
\text { Sucrose for } \\
\text { one week }\end{array}$ & 105 & $\begin{array}{c}\text { Different } \\
\text { painful } \\
\text { procedures }\end{array}$ & $0,+30$ & $54 \%$ & -10 & Not stated & Not stated & $\begin{array}{c}\text { Not } \\
\text { significant }\end{array}$ \\
\hline \multicolumn{13}{|l|}{ Painful + Handling } \\
\hline $\begin{array}{l}\text { Magnano et al. } 1992 \\
\text { USA [52] }\end{array}$ & $30-37$ & $5-53$ & $\begin{array}{l}\text { Two group } \\
\text { comparative } \\
\text { design }\end{array}$ & $\begin{array}{l}\text { Control vs. } \\
\text { Cocaine } \\
\text { exposed } \\
\text { infants }\end{array}$ & $47+11$ & $\begin{array}{l}\text { Heel lance } \\
\text { and Physical } \\
\text { exam. }\end{array}$ & $0,+30$ & $79 \%$ & Not stated & RIA & $3.3 / 10.1$ & $\begin{array}{l}\text { Increase \# and } \\
\text { Increase } \#\end{array}$ \\
\hline $\begin{array}{l}\text { Davis et al. } 2004 \\
\text { USA [53] }\end{array}$ & $33-34$ & $3-6$ & $\begin{array}{l}\text { Two group } \\
\text { comparative } \\
\text { design }\end{array}$ & $\begin{array}{c}\text { Control vs. } \\
\text { Antenatal } \\
\text { Betam-ethasone }\end{array}$ & $9+9$ & $\begin{array}{l}\text { Heel lance } \\
\text { and Physical } \\
\text { exam. }\end{array}$ & $\begin{array}{l}0,+20-25, \\
+40-45\end{array}$ & $98 \%$ & -20 & DELFIA & $4.3 / 11.99$ & $\begin{array}{l}\text { Decrease \#\# } \\
\text { and Increase }\end{array}$ \\
\hline
\end{tabular}


Table 1. Cont

\begin{tabular}{|c|c|c|c|c|c|c|c|c|c|c|c|c|}
\hline Author Year Country & 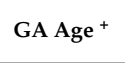 & $\begin{array}{l}\text { Post-Natal } \\
\text { Age, Days }\end{array}$ & Design & Study Groups & $n$ & Intervention & $\begin{array}{l}\text { Sampling } \\
\text { Times }\end{array}$ & $\begin{array}{l}\text { Successful Saliva } \\
\text { Sampling }\end{array}$ & $\begin{array}{c}\text { Storage } \\
\text { Temperature }\left({ }^{\circ} \mathrm{C}\right)\end{array}$ & $\begin{array}{l}\text { Analyze } \\
\text { Method }\end{array}$ & $\begin{array}{l}\text { Intra/Inter } \\
\text { CV }\end{array}$ & $\begin{array}{c}\text { Cortisol } \\
\text { Response }\end{array}$ \\
\hline \multicolumn{13}{|l|}{ Handling } \\
\hline $\begin{array}{l}\text { Mörelius et al. } 2006 \\
\text { Sweden [29] }\end{array}$ & $23-38$ & $\begin{array}{c}2-7 \text { and } \\
10-18\end{array}$ & $\begin{array}{l}\text { Two group } \\
\text { comparative } \\
\text { design }\end{array}$ & $\begin{array}{l}\text { Full-term vs. } \\
\text { preterm }\end{array}$ & $39+30$ & $\begin{array}{l}\text { Diaper } \\
\text { change }\end{array}$ & $0,+30$ & $90 \%$ & -22 & RIA & $/ 6.0-12.0$ & $\begin{array}{l}\text { Not } \\
\text { significant }\end{array}$ \\
\hline $\begin{array}{l}\text { Mörelius et al. } 2012 \\
\text { Sweden [54] }\end{array}$ & $24-37$ & $\leqslant 112$ & $\begin{array}{l}\text { Randomized } \\
\text { clinical study }\end{array}$ & $\begin{array}{l}\text { Standard care } \\
\text { vs. family care }\end{array}$ & $137+152$ & $\begin{array}{l}\text { Diaper } \\
\text { change }\end{array}$ & $0,+30$ & $97 \%$ & -22 & RIA & $/ 6.0-12.0$ & $\begin{array}{c}\text { Not } \\
\text { significant }\end{array}$ \\
\hline $\begin{array}{l}\text { Candia et al. } 2014 \\
\text { Brazil [55] }\end{array}$ & $26-36$ & $1-33$ & Single group & $\begin{array}{l}\text { Lateral/supine } \\
\text { position } v s . \\
\text { Prone position }\end{array}$ & 21 & $\begin{array}{l}\text { Prone } \\
\text { position }\end{array}$ & $0,+30$ & $76 \%$ & Not stated & ECL & Not stated & Decrease ${ }^{\# \#}$ \\
\hline \multicolumn{13}{|l|}{ Pleasant } \\
\hline $\begin{array}{l}\text { Mörelius et al. } 2005 \\
\text { Sweden [56] }\end{array}$ & $25-33$ & $\begin{array}{c}2-21 \text { and } \\
4-26\end{array}$ & Crossover & $\begin{array}{c}\text { Incubator care } \\
\text { vs. SSC }\end{array}$ & 17 & SSC & $0,+30$ & $89 \%$ & -22 & RIA & $/ 6.0-12.0$ & $\begin{array}{c}\text { Not } \\
\text { significant }\end{array}$ \\
\hline $\begin{array}{l}\text { Dorn et al. } 2014 \\
\text { Germany [57] }\end{array}$ & $30-37$ & Mean 4.9 & $\begin{array}{l}\text { Randomized } \\
\text { clinical study }\end{array}$ & $\begin{array}{c}\text { Control vs. } \\
\text { Music vs. } \\
\text { Maternal voice }\end{array}$ & $22+20+20$ & $\begin{array}{l}\text { Music and } \\
\text { Maternal } \\
\text { voice }\end{array}$ & $-10,+10$ & $65 \%$ & -20 & ELISA & Not stated & $\begin{array}{c}\text { Not } \\
\text { significant }\end{array}$ \\
\hline $\begin{array}{l}\text { Schwilling et al. } 2015 \\
\text { Germany [58] }\end{array}$ & $23-33$ & $<21$ & Single group & $\begin{array}{l}\text { Day 1 } \\
\text { Day 2 } \\
\text { Day 3 }\end{array}$ & 20 & Music & $0,+25,+4 \mathrm{~h}$ & $91 \%$ & -20 & $\begin{array}{c}\text { Mass- } \\
\text { spec-trometry }\end{array}$ & Not stated & Decrease ${ }^{\#}$ \\
\hline
\end{tabular}

${ }^{+}$Gestational age in weeks at birth; ${ }^{\prime}$ See Table 2 for details; ${ }^{\# \#}$ See Table 3 for details; ${ }^{*}$ Only reports how many subjects provided complete set of data, not how many were included. RIA = Radioimmunoassay; ELISA= Enzyme-linked immunosorbent assay; ECL = Electrochemiluminescence; EIA = Sensitive enzyme immunoassay; DELFIA = Competitive solid phase time-resolved fluorescence immunoassay with fluorometric endpoint. 


\subsection{Analysis Method}

The effect size was not calculated in this integrative review since less than half of the studies presented mean and standard deviations while the other studies presented median values or just showed the cortisol levels in graphs. Instead, we examined and summarized whether the change in salivary cortisol from the baseline to response was statistically significant or not, and if so, in which direction [24]. The directions were classified as an increase or decrease. If the study involved the presentation of salivary cortisol results for both preterm and full-term infants, information from the preterm infants was extracted.

\section{Results}

\subsection{Characteristics and Quality of Included Studies}

Table 1 shows the descriptive data of the included studies. Ten studies included infants born $\leqslant 28$ weeks gestational age (GA) [29,47-51,54-56,58]. Of the studies comparing data between two groups, four studies recruited $\geqslant 50$ infants in each group [46,47,51,54]. All studies but one [57] collected response samples at the recommended time of 20-30 min [59]. Several studies reported problems with saliva collection from preterm infants; six studies reported a successful saliva sampling rate $\geqslant 90 \%[29,44,50,53,54,58]$. Five studies $[44,46,47,52,55]$ did not state the storage temperature of the saliva samples and one study [51] reported a storage temperature above the recommended $-20{ }^{\circ} \mathrm{C}$, which may have increased the risk of evaporation [60]. Two studies did not report the analysis methods for salivary cortisol $[45,51]$. Seven studies did not report the coefficient of variation for the methods used $[44,46,47,51,55,57,58]$, which makes it more difficult to interpret the quality of the analysis method.

Among the seven studies comparing salivary cortisol reactivity between two different preterm groups, three studies included the mode of delivery as a background variable $[48,53,54]$. One study found a significant difference in the mode of delivery between groups but did not control for mode of delivery in the statistical analysis of cortisol reactivity [48]. All studies except two [52,53] reported obtaining approval from an ethical board.

\subsection{Interventions Leading to a Change in Salivary Cortisol from Baseline}

The interventions that were found to lead to an increase in salivary cortisol levels from the baseline were the heel lance, physical examination, and eye-screening examination (Table 2). The interventions that were found to lead to a decrease in salivary cortisol levels from the baseline were prone position and live harp music (Table 3). However, the heel lance and eye-screening examination also led to a decrease in cortisol when non-pharmacological methods aiming to reduce pain were used, i.e., co-bedding of twins or behavioral support according to the Newborn Individualized Developmental Care and Assessment Program (NIDCAP) (Table 3). The interventions used in the reviewed studies are classified as painful, handling, or pleasant in this report.

Table 2. Studies reporting an increase in salivary cortisol levels from the baseline with different interventions $(n=3)$.

\begin{tabular}{lll}
\hline Author Year & Intervention & Results \\
\hline Magnano 1992 [52] & Heel lance & $\begin{array}{l}\text { Cocaine-exposed as well as non-cocaine-exposed infants showed a significant } \\
\text { increase in salivary cortisol 30 min after heel lance. }\end{array}$ \\
\cline { 2 - 3 } Physical examination & $\begin{array}{l}\text { Non-cocaine-exposed infants showed a significant increase in salivary cortisol } \\
30 \text { min after physical examination. }\end{array}$ \\
\hline Kleberg 2008 [49] & Heel lance & $\begin{array}{l}\text { Infants not exposed to antenatal betamethasone showed a significant increase in } \\
\text { salivary cortisol 20 min after heel lance. }\end{array}$ \\
\hline & Eye-screening & $\begin{array}{l}\text { NIDCAP treated as well as non-NIDCAP treated infants showed a significant } \\
\text { increase in salivary cortisol from the baseline to 30 and 60 min after eye-screening } \\
\text { examination for retinopathy of the premature eye. }\end{array}$ \\
\hline
\end{tabular}




\subsection{Summary of Painful, Handling, and Pleasant Interventions}

\subsubsection{Painful Interventions}

The painful interventions from the reviewed studies included the heel lance, eye-screening examination, nasopharyngeal suctioning, and "different painful procedures". Seven studies used the heel lance as a painful intervention $[44-48,52,53]$. Two of these studies reported significant increases from the baseline in salivary cortisol levels in preterm infants born > 30 weeks GA [52,53]. Magnano and colleagues compared 11 infants exposed to cocaine in utero with 47 infants not exposed to cocaine and found an increase in salivary cortisol level in response to the heel lance in both groups [52]. Davis et al. compared nine infants exposed to antenatal betamethasone with nine unexposed infants and found a significant increase in salivary cortisol levels in response to the heel lance among the unexposed infants and a significant decrease in salivary cortisol levels among the betamethasone-exposed infants [53] (Table 2). A significant decrease in salivary cortisol levels in relation to the heel lance was reported by Campbell-Yeo et al. [48]. They compared twins exposed to the heel lance whereby one group was randomized to co-bedding at least $24 \mathrm{~h}$ before the heel lance. Regardless of group assignment, all infants received one dose of oral $24 \%$ sucrose $2 \mathrm{~min}$ before the heel lance and were offered a pacifier. The results showed a significant decrease in salivary cortisol levels in the twins having the co-bedding experience $(n=72)$ but not in the control group $(n=62)$ (Table 3$)$. One article using the heel lance as an intervention found no significant changes in salivary cortisol levels when administrating pain relief, i.e., oral sucrose, to the infants [44] (Table 1).

Table 3. Studies reporting a decrease in salivary cortisol levels from the baseline with different interventions $(n=5)$.

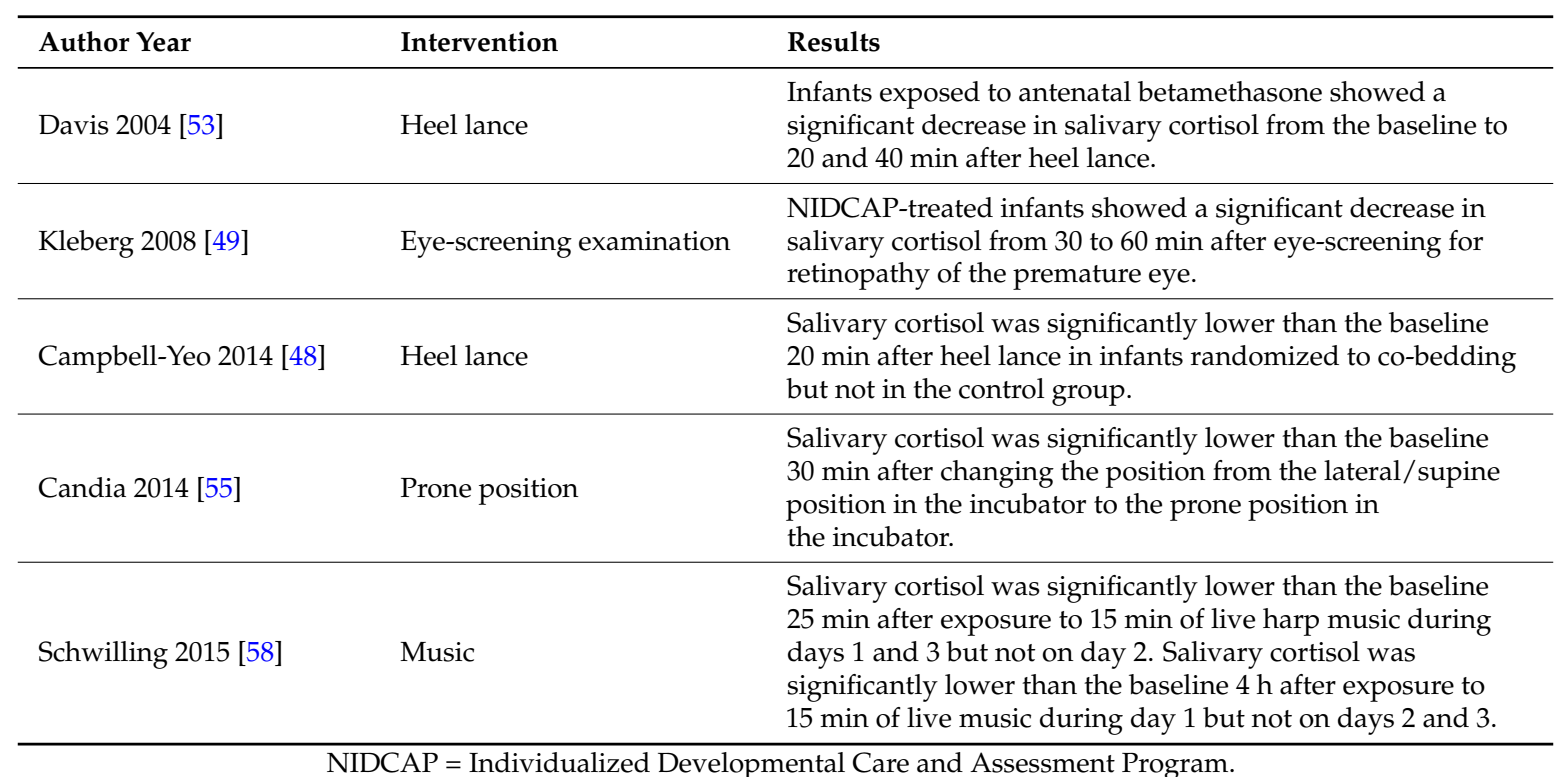

Three studies reported differences between the intervention and control groups in salivary cortisol levels after the heel lance but did not provide significance levels for cortisol reactivity for each group [45-47]. Cong et al. performed a crossover trial comparing infants when they were exposed to SSC prior to and during the heel lance with incubator care [45]. They found that $20 \mathrm{~min}$ after the heel lance, infants exposed to SSC for $30 \mathrm{~min}(n=18)$ had lower salivary cortisol compared to those in the control group whose heel lance was performed in the incubator [45]. Badiee et al. compared infants either exposed to formula milk odor or breast milk odor during the heel lance. Infants exposed to maternal breast milk odor $(n=25)$ had significantly lower salivary cortisol levels 20 min after the heel lance compared to infants exposed to formula milk odor $(n=25)$ [46]. In 2014, Badiee and her colleagues performed another trial with twins randomized to co-bedding in the incubator or separate 
bedding. Infants co-bedded $24 \mathrm{~h}$ prior to the heel lance $(n=50)$ had significantly lower salivary cortisol levels $20 \mathrm{~min}$ after a heel lance compared to infants randomized to separate bedding $(n=50)$ [47] (Table 1).

Salivary cortisol reactivity has also been studied in relation to "different painful procedures" (e.g., heel lance, venipuncture, and suctioning) [51], nasopharyngeal suctioning [50], and the eye-screening examination [49] (Table 1). The first two studies reported no significant change in cortisol levels between the baseline and response. Kleberg et al. performed a randomized crossover trial with 36 infants randomly assigned at the first eye-screening examination to receive either behavioral support according to NIDCAP or standard care. The eye-screening examination provoked an increase in salivary cortisol from the baseline at both 30 and $60 \mathrm{~min}$ after the examination in both groups [49] (Table 2).

\subsubsection{Handling Interventions}

The handling interventions from the reviewed studies included physical examination, prone position, and diaper change. Five studies used handling as an intervention [29,52-55]. Magnano and colleagues found a significant increase in salivary cortisol in non-cocaine-exposed infants $(n=47)$ in response to physical examination but not for cocaine-exposed infants $(n=11)$ [52] (Table 2). Davis et al. reported non-significant results in response to physical examination in both antenatal betamethasone-exposed infants $(n=9)$ and non-exposed infants $(n=9)$ [53] (Table 1).

Changing to the prone position was used as an intervention in one study [55]. In a single group $(n=21)$, Candida et al. found a significant decrease in salivary cortisol $30 \mathrm{~min}$ after changing infants' position from the lateral/supine position to the prone position in the incubator [55] (Table 3).

Mörelius and colleagues compared preterm infants $(n=30)$ with full-term infants $(n=39)$ in response to a standardized diaper change performed by staff during the first and the fourth weeks of life. There were significant differences in cortisol levels between preterm and full-term infants but no significant difference between baseline and response values [29]. In 2012, Mörelius and her colleagues again used a diaper change as an intervention, but this time the mother changed the diaper instead of staff. Infants randomized to a family-centered NICU $(n=152)$ where the parents stayed around the clock were compared with infants in a ward where the parents had to sleep at home $(n=132)$. No significant differences in salivary cortisol reactivity were found in either group [54].

\subsubsection{Pleasant Interventions}

The pleasant interventions from the reviewed studies included music, acoustic stimulation, maternal voice, and SSC. Three studies used pleasant interventions [56-58]. Schwilling et al. [58] introduced a single group of infants $(n=20)$ to live harp music for $15 \mathrm{~min}$ a day for three consecutive days and found decreased salivary cortisol levels in response to the music on days one and three but not on day two. The salivary cortisol level was also significantly lower than the baseline $4 \mathrm{~h}$ after exposure to music during day one but not on days two and three (Table 3). Similarly, Dorn and colleagues [57] studied the influence of acoustic stimulation and randomized 60 infants to three groups; audiotaped lullabies, maternal voice, and control. Infants in the audiotaped lullabies and maternal voice groups were exposed to acoustic stimulation for 30 min every day over a period of two weeks. No significant changes in salivary cortisol reactivity were found. One study investigated salivary cortisol reactivity during SSC. Cortisol was measured at three time points (in the incubator, during SSC, and back in the incubator) on two different occasions (first and fourth SSC). No significant results in cortisol reactivity were found [56] (Table 1).

\section{Discussion}

This review summarizes the evidence of painful, handling, or pleasant interventions that caused a change in salivary cortisol from baseline in preterm infants in the NICU. 
Two studies reported significantly increased salivary cortisol levels among preterm infants after exposure to a painful procedure [49,52]. These two studies, which recruited preterm infants born at 23-37 weeks GA, reported a successful saliva sampling above $75 \%$ and showed significant results despite relatively small sample sizes $[49,52]$. The result is congruent with previous studies, which found that healthy infants usually show an elevation in cortisol in response to painful procedures [24,41]. A reaction to pain is a defense mechanism aiming to protect the person from harm and to maintain homeostasis, and strong stimuli such as pain tends to yield non-habituation in healthy infants [61,62].

It is well known that pain relief such as sweet-tasting oral solutions and non-nutritive sucking have proven to be effective in reducing pain during single painful procedures in newborns [63-66]. The administration of optimal pain relief probably explains the absence of salivary cortisol reactivity in response to the heel lance in the study by Cignacco et al. [44]. In the study of Campbell-Yeo et al. [48], infants were given oral sucrose and a pacifier before the heel lance, and co-bedded twins experienced a decrease in salivary cortisol levels, but not separated twins. A dampened cortisol response in infants receiving a pacifier and a sweet-tasting oral solution during a painful procedure is likely to reflect an absence or a lower degree of pain and stress. A significant decrease in response to the heel lance without any pain relief as with the infants exposed to antenatal betamethasone in the study by Davis et al. [53] is more likely to be an effect of suppressed adrenal activity due to the corticosteroid use [67], which is not the same as no pain or stress. It is also possible that co-bedded twins were experiencing relief due to the reunion, which affected the adrenocortical response through human touch and closeness $[34,36,68]$. Thus, it is possible that the cortisol level decrease was exclusively due to co-bedding the twins. However, it is noteworthy that the nurses who performed the heel lances in the study by Campbell-Yeo et al. were not blinded to group assignment and the successful saliva sampling was rather low [48]. Badiee et al. revealed similar results. They found a significantly higher cortisol level after the heel lance in the standard care group compared to the co-bedding group, but did not provide cortisol reactivity results [47]. However, the results are promising and, therefore, the replicability of these findings needs to be further investigated. Kleberg et al. used behavioral support but found no effect of NIDCAP on cortisol levels during the eye-screening examination. However, they found a more rapid recovery in the NIDCAP group [49]. Recovery, the degree to which cortisol elevations persist after termination of the stressor [69], was studied in only two of the included articles $[49,53]$. Since preterm infants are subjected to several procedures each day, it is important to continue to investigate the recovery from stressful stimuli in preterm infants in order to learn more about their stress system development and to be able to provide optimal support in the NICU.

Few reviewed studies used handling as a stressor [29,52-55]. Magnano and colleagues found that healthy preterm infants did not respond to a physical examination while antenatal cocaine-exposed infants' salivary cortisol levels increased [52]. This result is in accordance with the theory of habituation. Repeated milder stressors that do not involve a threat to physical or psychological well-being may yield habituation of the adrenocortical response in healthy infants but not necessarily in unhealthy infants [61,62].

It is of the utmost importance to find care methods that can buffer stress and, thus, longstanding elevated levels of cortisol in preterm infants in the NICU. Two studies found decreased salivary cortisol levels in response to a changed positioning from lateral/supine to prone and live harp music, respectively $[57,58]$. However, both studies used the single group method, which makes it difficult to determine whether the decrease in cortisol levels was due to the intervention or a natural decline in cortisol levels [7]. Moreover, coefficients of variation for the assay methods were not reported, which affects the reliability. Since the results are important and interesting, both studies should be repeated using a randomized, controlled study design.

An absence of cortisol response in a stressful situation which may threaten the homeostasis of the premature infant may have several causes. First, suppressed adrenal activity due to corticosteroid treatment [67] or longstanding high stress load leading to allostatic load and an inability to respond [23]. Second, a high baseline value, resulting in a smaller rise as explained by the law of initial value [70]. 
Third, immaturity of the HPA axis system causing inconsistent, less robust cortisol responses [4]. Fourth, the stressor is too mild and/or the infant has become habituated to the procedure [62]. Fifth, methodological issues such as study design, lack of power, saliva collection time, and quality of the cortisol analysis method.

In this review, several studies reported an absence of cortisol response in relation to painful procedures [44,50,51], handling [29,54], and pleasant interventions [56,57]. Boyer et al. presented some methodological issues with low successful saliva sampling and no report of analysis method [51]. Dorn et al. [57] reported a rather low rate of successful saliva sampling, no intra-assay coefficient of variation, and moreover collected response values after $10 \mathrm{~min}$ instead of the recommended 20-30 min [59]. In studies by Ivars et al. and Mörelius et al. 2006 and 2012, it is plausible that the stressors were too mild for rather stable infants, and so the studies ought to be repeated with more well-defined groups comprising only infants with low GA and low postnatal age $[29,50,54]$. If the parent is performing the diaper change, it is also important to control for parental sensitivity and SSC, since both parental sensitivity and SSC may buffer the infant's stress reaction [34,36,71]. In 2005, Mörelius et al. included infants with a wide range of GA from 25 to 33 weeks during SSC [56]. The results show a large variability in the cortisol responses with both elevated and decreased levels reflecting an immature HPA axis. Several studies included in this review examined an unselected group of preterm infants in terms of GA. Extremely preterm infants are more immature and there is no correlation between ACTH and cortisol as there is in more mature infants [19]. Hence, researchers should consider the GA of preterm infants when designing studies of salivary cortisol reactivity in the future, and should aim at creating more homogenous groups for better comparison.

Other methodological issues such as obtaining optimal sample volumes of saliva without using a saliva stimulant could be reasons for the small number of studies performed in the NICU. A sampling time exceeding $5 \mathrm{~min}$ [57], cheek massage [48], or aspiration of saliva with a syringe [53,55] may be stressors in themselves and may confound the cortisol results. It is therefore valuable to adopt non-invasive sampling methods as well as measurement methods using minute sample volumes when studying salivary cortisol in preterm infants [72-74].

In this review, we have summarized the cortisol reactivity in relation to different interventions but we have not evaluated the interventions per se. Thus, it is possible that the included interventions, e.g., diaper change and SSC, may still be stressful or have a calming effect for the preterm infants in the NICU even though there was no change in cortisol levels. Studies that did not report ethical approval were also included in this review and the advisability of such inclusion may be debatable. However, the reasons for inclusion of these studies were that both studies used stressors that were part of the infants' care and the results are valuable for the understanding of stress reactivity in preterm infants.

\section{Conclusions}

Salivary cortisol has been used as a marker of stress in preterm infants in the NICU since 1992. This integrative review showed that painful interventions, such as the heel lance and eye-screening examination, could lead to an elevation in salivary cortisol levels from the baseline in preterm infants in the NICU. Pain relief and antenatal glucocorticoids may dampen the response for different reasons. Changing to the prone position and exposure to live harp music were promising interventions that could lead to a decrease in salivary cortisol levels from baseline. However, these interventions need to be further investigated with designs comprising control groups. Several studies report a low percentage of successful saliva sampling. For future studies, it is important to utilize analysis methods using minute saliva sample volumes in order to increase reliability. In addition, the stressfulness of many interventions routinely performed in the NICU has never been evaluated with salivary cortisol, and future studies should focus on interventions that involve the infant and the infant's nest such as changing of cot-sheets, personal hygiene care, and separation from the parent.

Acknowledgments: No funding was secured for this study. 
Author Contributions: Mörelius conceptualized and designed the study, performed the data search, reviewed the articles and drafted the initial manuscript. He critically reviewed the data search, the article review, and the manuscript. Shorey critically reviewed the data search, the article review, and the manuscript. All authors approved the final manuscript as submitted.

Conflicts of Interest: The authors declare no conflict of interest. The authors have no financial relationships relevant to this article.

\section{Abbreviations}

The following abbreviations are used in this manuscript:

$\begin{array}{ll}\text { ACTH } & \text { Adrenocorticotropic hormone } \\ \text { CV } & \text { Coefficient of variation } \\ \text { GA } & \text { Gestational age } \\ \text { HPA } & \text { Hypothalamic-pituitary-adrenal } \\ \text { NICU } & \text { Neonatal intensive care unit } \\ \text { NIDCAP } & \text { Newborn individualized developmental care and assessment program } \\ \text { SSC } & \text { Skin-to-skin contact }\end{array}$

\section{References}

1. Levine, S. Developmental determinants of sensitivity and resistance to stress. Psychoneuroendocrinology 2005, 30, 939-946. [CrossRef] [PubMed]

2. Gitau, R.; Fisk, N.M.; Glover, V. Human fetal and maternal corticotrophin releasing hormone responses to acute stress. Arch. Dis Child. Fetal Neonatal Ed. 2004, 89, F29-F32. [CrossRef] [PubMed]

3. Feldman, R.; Singer, M.; Zagoory, O. Touch attenuates infants' physiological reactivity to stress. Dev. Sci. 2010, 13, 271-278. [CrossRef] [PubMed]

4. Bolt, R.J.; Van Weissenbruch, M.M.; Popp-Snijders, C.; Sweep, F.G.; Lafeber, H.N.; Delemarre-van de Waal, H.A. Maturity of the adrenal cortex in very preterm infants is related to gestational age. Pediatr. Res. 2002, 52, 405-410. [CrossRef] [PubMed]

5. Murphy, B.E. Cortisol and cortisone in human fetal development. J. Steroid. Biochem. 1979, 11, 509-513. [CrossRef]

6. Hillman, N.H.; Kallapur, S.G.; Jobe, A.H. Physiology of transition from intrauterine to extrauterine life. Clin. Perinatol. 2012, 39, 769-783. [CrossRef] [PubMed]

7. Ivars, K.; Nelson, N.; Theodorsson, A.; Theodorsson, E.; Strom, J.O.; Mörelius, E. Development of salivary cortisol circadian rhythm and reference intervals in full-term infants. PloS ONE 2015, 10, e0129502. [CrossRef] [PubMed]

8. Watterberg, K.L.; Scott, S.M. Evidence of early adrenal insufficiency in babies who develop bronchopulmonary dysplasia. Pediatrics 1995, 95, 120-125. [PubMed]

9. Fernandez, E.F.; Watterberg, K.L. Relative adrenal insufficiency in the preterm and term infant. J. Perinatol. 2009, 29 (Suppl. 2), S44-S49. [CrossRef] [PubMed]

10. Grunau, R.E.; Whitfield, M.F.; Petrie-Thomas, J.; Synnes, A.R.; Cepeda, I.L.; Keidar, A.; Rogers, M.; Mackay, M.; Hubber-Richard, P.; Johannesen, D. Neonatal pain, parenting stress and interaction, in relation to cognitive and motor development at 8 and 18 months in preterm infants. Pain 2009, 143, 138-146. [CrossRef] [PubMed]

11. Lombroso, P.J.; Sapolsky, R. Development of the cerebral cortex: XII Stress and brain development: I. J. Am. Acad. Child Adolesc. Psychiatry 1998, 37, 1337-1339. [CrossRef] [PubMed]

12. Haley, D.W.; Weinberg, J.; Grunau, R.E. Cortisol, contingency learning, and memory in preterm and full-term infants. Psychoneuroendocrinology 2006, 31, 108-117. [CrossRef] [PubMed]

13. Quesada, A.A.; Tristao, R.M.; Pratesi, R.; Wolf, O.T. Hyper-responsiveness to acute stress, emotional problems and poorer memory in former preterm children. Stress 2014, 17, 389-399. [CrossRef] [PubMed]

14. Wadsby, M.; Nelson, N.; Ingemansson, F.; Samuelsson, S.; Leijon, I. Behaviour problems and cortisol levels in very-low-birth-weight children. Nord. J. Psychiatry 2014, 68, 626-632. [CrossRef] [PubMed]

15. Johnston, C.; Barrington, K.J.; Taddio, A.; Carbajal, R.; Filion, F. Pain in Canadian NICUS: Have we improved over the past 12 years? Clin. J. Pain 2011, 27, 225-232. [CrossRef] [PubMed] 
16. Grunau, R.E.; Haley, D.W.; Whitfield, M.F.; Weinberg, J.; Yu, W.; Thiessen, P. Altered basal cortisol levels at 3, 6, 8 and 18 months in infants born at extremely low gestational age. J. Pediatr. 2007, 150, 151-156. [CrossRef] [PubMed]

17. Brummelte, S.; Chau, C.M.; Cepeda, I.L.; Degenhardt, A.; Weinberg, J.; Synnes, A.R.; Grunau, R.E. Cortisol levels in former preterm children at school age are predicted by neonatal procedural pain-related stress. Psychoneuroendocrinology 2015, 51, 151-163. [CrossRef] [PubMed]

18. Grunau, R.E.; Weinberg, J.; Whitfield, M.F. Neonatal procedural pain and preterm infant cortisol response to novelty at 8 months. Pediatrics 2004, 114, e77-e84. [CrossRef] [PubMed]

19. Holsti, L.; Weinberg, J.; Whitfield, M.F.; Grunau, R.E. Relationships between adrenocorticotropic hormone and cortisol are altered during clustered nursing care in preterm infants born at extremely low gestational age. Early Hum. Dev. 2007, 83, 341-348. [CrossRef] [PubMed]

20. Grunau, R.E.; Holsti, L.; Haley, D.W.; Oberlander, T.; Weinberg, J.; Solimano, A.; Whitfield, M.F.; Fitzgerald, C.; $\mathrm{Yu}, \mathrm{W}$. Neonatal procedural pain exposure predicts lower cortisol and behavioral reactivity in preterm infants in the NICU. Pain 2005, 113, 293-300. [CrossRef] [PubMed]

21. Anand, K.J. Clinical importance of pain and stress in preterm neonates. Biol. Neonate 1998, 73, 1-9. [CrossRef] [PubMed]

22. Owens, R. Intraventricular hemorrhage in the premature neonate. Neonatal Netw. 2005, 24, 55-71. [CrossRef] [PubMed]

23. McEwen, B.S.; Wingfield, J.C. The concept of allostasis in biology and biomedicine. Horm. Behav. 2003, 43, 2-15. [CrossRef]

24. Gunnar, M.R.; Talge, N.M.; Herrera, A. Stressor paradigms in developmental studies: What does and does not work to produce mean increases in salivary cortisol. Psychoneuroendocrinology 2009, 34, 953-967. [CrossRef] [PubMed]

25. Comaru, T.; Miura, E. Postural support improves distress and pain during diaper change in preterm infants. J. Perinatol. 2009, 29, 504-507. [CrossRef] [PubMed]

26. Lyngstad, L.T.; Tandberg, B.S.; Storm, H.; Ekeberg, B.L.; Moen, A. Does skin-to-skin contact reduce stress during diaper change in preterm infants? Early Hum. Dev. 2014, 90, 169-172. [CrossRef] [PubMed]

27. Pokela, M.L. Pain relief can reduce hypoxemia in distressed neonates during routine treatment procedures. Pediatrics 1994, 93, 379-383. [PubMed]

28. Yung-Weng, W.; Ying-Ju, C. A preliminary study of bottom care effects on premature infants' heart rate and oxygen saturation. J. Nurs Res. 2004, 12, 161-168. [PubMed]

29. Mörelius, E.; Hellstrom-Westas, L.; Carlen, C.; Norman, E.; Nelson, N. Is a nappy change stressful to neonates? Early Hum. Dev. 2006, 82, 669-676. [CrossRef] [PubMed]

30. Neu, M.; Pan, Z.; Workman, R.; Marcheggiani-Howard, C.; Furuta, G.; Laudenslager, M.L. Benefits of massage therapy for infants with symptoms of gastroesophageal reflux disease. Bio. Res. Nurs. 2014, 16, 387-397. [CrossRef] [PubMed]

31. Kurihara, H.; Chiba, H.; Shimizu, Y.; Yanaihara, T.; Takeda, M.; Kawakami, K.; Takai-Kawakami, K. Behavioral and adrenocortical responses to stress in neonates and the stabilizing effects of maternal heartbeat on them. Early Hum. Dev. 1996, 46, 117-127. [CrossRef]

32. Mörelius, E.; Theodorsson, E.; Nelson, N. Stress at three-month immunization: Parents' and infants' salivary cortisol response in relation to the use of pacifier and oral glucose. Eur. J. Pain. 2009, 13, 202-208. [CrossRef] [PubMed]

33. South, M.M.; Strauss, R.A.; South, A.P.; Boggess, J.F.; Thorp, J.M. The use of non-nutritive sucking to decrease the physiologic pain response during neonatal circumcision: A randomized controlled trial. Am. J. Obstet. Gynecol. 2005, 193, 537-543. [CrossRef] [PubMed]

34. Mörelius, E.; Ortenstrand, A.; Theodorsson, E.; Frostell, A. A randomised trial of continuous skin-to-skin contact after preterm birth and the effects on salivary cortisol, parental stress, depression, and breastfeeding. Early Hum. Dev. 2015, 91, 63-70. [CrossRef] [PubMed]

35. Neu, M.; Hazel, N.A.; Robinson, J.; Schmiege, S.J.; Laudenslager, M. Effect of holding on co-regulation in preterm infants: A randomized controlled trial. Early Hum. Dev. 2014, 90, 141-147. [CrossRef] [PubMed]

36. Feldman, R.; Rosenthal, Z.; Eidelman, A.I. Maternal-preterm skin-to-skin contact enhances child physiologic organization and cognitive control across the first 10 years of life. Biol. Psychiatr. 2014, 75, 56-64. [CrossRef] [PubMed] 
37. Taylor, A.; Fisk, N.M.; Glover, V. Mode of delivery and subsequent stress response. Lancet 2000, $355,120$. [CrossRef]

38. Schuller, C.; Kanel, N.; Muller, O.; Kind, A.B.; Tinner, E.M.; Hosli, I.; Zimmermann, R.; Surbek, D. Stress and pain response of neonates after spontaneous birth and vacuum-assisted and cesarean delivery. Am. J. Obstet. Gynecol. 2012, 207, e411-e416. [CrossRef] [PubMed]

39. O'Connor, T.G.; Bergman, K.; Sarkar, P.; Glover, V. Prenatal cortisol exposure predicts infant cortisol response to acute stress. Dev. Psychobiol. 2013, 55, 145-155. [CrossRef] [PubMed]

40. Dickerson, S.S.; Kemeny, M.E. Acute stressors and cortisol responses: A theoretical integration and synthesis of laboratory research. Psychol. Bull. 2004, 130, 355-391. [CrossRef] [PubMed]

41. Jansen, J.; Beijers, R.; Riksen-Walraven, M.; de Weerth, C. Cortisol reactivity in young infants. Psychoneuroendocrinology 2010, 35, 329-338. [CrossRef] [PubMed]

42. Francis, S.J.; Walker, R.F.; Riad-Fahmy, D.; Hughes, D.; Murphy, J.F.; Gray, O.P. Assessment of adrenocortical activity in term newborn infants using salivary cortisol determinations. J. Pediatr. 1987, 111, 129-133. [CrossRef]

43. Schwartz, E.B.; Granger, D.A.; Susman, E.J.; Gunnar, M.R.; Laird, B. Assessing salivary cortisol in studies of child development. Child. Dev. 1998, 69, 1503-1513. [CrossRef] [PubMed]

44. Cignacco, E.; Denhaerynck, K.; Nelle, M.; Buhrer, C.; Engberg, S. Variability in pain response to a non-pharmacological intervention across repeated routine pain exposure in preterm infants: A feasibility study. Acta Paediatr. 2009, 98, 842-846. [CrossRef] [PubMed]

45. Cong, X.; Ludington-Hoe, S.M.; Walsh, S. Randomized crossover trial of kangaroo care to reduce biobehavioral pain responses in preterm infants: A pilot study. Biol. Res. Nurs. 2011, 13, 204-216. [CrossRef] [PubMed]

46. Badiee, Z.; Asghari, M.; Mohammadizadeh, M. The calming effect of maternal breast milk odor on premature infants. Pediatr. Neonatol. 2013, 54, 322-325. [CrossRef] [PubMed]

47. Badiee, Z.; Nassiri, Z.; Armanian, A. Cobedding of twin premature infants: Calming effects on pain responses. Pediatr. Neonatol. 2014, 55, 262-268. [CrossRef] [PubMed]

48. Campbell-Yeo, M.L.; Johnston, C.C.; Joseph, K.S.; Feeley, N.; Chambers, C.T.; Barrington, K.J.; Walker, C.D. Co-bedding between preterm twins attenuates stress response after heel lance: Results of a randomized trial. Clin. J. Pain 2014, 30, 598-604. [PubMed]

49. Kleberg, A.; Warren, I.; Norman, E.; Morelius, E.; Berg, A.C.; Mat-Ali, E.; Holm, K.; Fielder, A.; Nelson, N.; Hellstrom-Westas, L. Lower stress responses after newborn individualized developmental care and assessment program care during eye screening examinations for retinopathy of prematurity: A randomized study. Pediatrics 2008, 121, e1267-e1278. [CrossRef] [PubMed]

50. Ivars, K.; Nelson, N.; Finnstrom, O.; Morelius, E. Nasopharyngeal suctioning does not produce a salivary cortisol reaction in preterm infants. Acta Paediatr. 2012, 101, 1206-1210. [CrossRef] [PubMed]

51. Boyer, K.; Johnston, C.; Walker, C.D.; Filion, F.; Sherrard, A. Does sucrose analgesia promote physiologic stability in preterm neonates? Biol. Neonate 2004, 85, 26-31. [CrossRef] [PubMed]

52. Magnano, C.L.; Gardner, J.M.; Karmel, B.Z. Differences in salivary cortisol levels in cocaine-exposed and noncocaine-exposed NICU infants. Dev. Psychobiol. 1992, 25, 93-103. [CrossRef] [PubMed]

53. Davis, E.P.; Townsend, E.L.; Gunnar, M.R.; Georgieff, M.K.; Guiang, S.F.; Ciffuentes, R.F.; Lussky, R.C. Effects of prenatal betamethasone exposure on regulation of stress physiology in healthy premature infants. Psychoneuroendocrinology 2004, 29, 1028-1036. [CrossRef] [PubMed]

54. Mörelius, E.; Brostrom, E.B.; Westrup, B.; Sarman, I.; Ortenstrand, A. The Stockholm neonatal family-centered care study: Effects on salivary cortisol in infants and their mothers. Early Hum. Dev. 2012, 88, 575-581. [CrossRef] [PubMed]

55. Candia, M.F.; Osaku, E.F.; Leite, M.A.; Toccolini, B.; Costa, N.L.; Teixeira, S.N.; Costa, C.R.; Piana, P.A.; Cristovam, M.A.; Osaku, N.O. Influence of prone positioning on premature newborn infant stress assessed by means of salivary cortisol measurement: Pilot study. Rev. Bras. Ter. Intensiva 2014, 26, 169-175. [CrossRef] [PubMed]

56. Mörelius, E.; Theodorsson, E.; Nelson, N. Salivary cortisol and mood and pain profiles during skin-to-skin care for an unselected group of mothers and infants in neonatal intensive care. Pediatrics 2005, 116, 1105-1113. [CrossRef] [PubMed] 
57. Dorn, F.; Wirth, L.; Gorbey, S.; Wege, M.; Zemlin, M.; Maier, R.F.; Lemmer, B. Influence of acoustic stimulation on the circadian and ultradian rhythm of premature infants. Chronobiol. Int. 2014, 31, 1062-1074. [CrossRef] [PubMed]

58. Schwilling, D.; Vogeser, M.; Kirchhoff, F.; Schwaiblmair, F.; Boulesteix, A.L.; Schulze, A.; Flemmer, A.W. Live music reduces stress levels in very low-birthweight infants. Acta Paediatr. 2015, 104, 360-367. [CrossRef] [PubMed]

59. Gunnar, M.R. Studies of the human infant's adrenocortical response to potentially stressful events. New Dir. Child. Dev. 1989, 3-18. [CrossRef]

60. Hanrahan, K.; McCarthy, A.M.; Kleiber, C.; Lutgendorf, S.; Tsalikian, E. Strategies for salivary cortisol collection and analysis in research with children. Appl. Nurs. Res. 2006, 19, 95-101. [CrossRef] [PubMed]

61. Thompson, R.F.; Spencer, W.A. Habituation: A model phenomenon for the study of neuronal substrates of behavior. Psychol. Rev. 1966, 73, 16-43. [CrossRef] [PubMed]

62. Gunnar, M.R.; Hertsgaard, L.; Larson, M.; Rigatuso, J. Cortisol and behavioral responses to repeated stressors in the human newborn. Dev. Psychobiol. 1991, 24, 487-505. [CrossRef] [PubMed]

63. Cignacco, E.; Hamers, J.P.; Stoffel, L.; van Lingen, R.A.; Gessler, P.; McDougall, J.; Nelle, M. The efficacy of non-pharmacological interventions in the management of procedural pain in preterm and term neonates. A systematic literature review. Eur. J. Pain 2007, 11, 139-152. [CrossRef] [PubMed]

64. Bueno, M.; Yamada, J.; Harrison, D.; Khan, S.; Ohlsson, A.; Adams-Webber, T.; Beyene, J.; Stevens, B. A systematic review and meta-analyses of nonsucrose sweet solutions for pain relief in neonates. Pain Res. Manag. 2013, 18, 153-161. [CrossRef] [PubMed]

65. Stevens, B.; Yamada, J.; Lee, G.Y.; Ohlsson, A. Sucrose for analgesia in newborn infants undergoing painful procedures. Cochrane Database Syst. Rev. 2013, 1, CD001069. [PubMed]

66. Field, T.; Goldson, E. Pacifying effects of nonnutritive sucking on term and preterm neonates during heelstick procedures. Pediatrics 1984, 74, 1012-1015. [PubMed]

67. Schaffer, L.; Luzi, F.; Burkhardt, T.; Rauh, M.; Beinder, E. Antenatal betamethasone administration alters stress physiology in healthy neonates. Obstet. Gynecol. 2009, 113, 1082-1088. [CrossRef] [PubMed]

68. Champagne, F.; Meaney, M.J. Like mother, like daughter: Evidence for non-genomic transmission of parental behavior and stress responsivity. Prog Brain Res. 2001, 133, 287-302. [PubMed]

69. Linden, W.; Earle, T.L.; Gerin, W.; Christenfeld, N. Physiological stress reactivity and recovery: Conceptual siblings separated at birth? J. Psychosom. Res. 1997, 42, 117-135. [CrossRef]

70. Wilder, J. Adrenalin and the law of initial value: A critical survey. Exp. Med. Surg. 1957, 15, 47-67. [PubMed]

71. Mörelius, E.; Nelson, N.; Gustafsson, P.A. Salivary cortisol response in mother-infant dyads at high psychosocial risk. Child Care Health Dev. 2007, 33, 128-136. [CrossRef] [PubMed]

72. Mörelius, E.; Theodorsson, E.; Nelson, N. Sample volume matters when sampling saliva in paediatric clinical analysis. Acta Paediatr. 2013, 102, e389. [CrossRef] [PubMed]

73. Mörelius, E.; Nelson, N.; Theodorsson, E. Salivary cortisol and administration of concentrated oral glucose in newborn infants: Improved detection limit and smaller sample volumes without glucose interference. Scand. J. Clin. Lab. Investig. 2004, 64, 113-118. [CrossRef]

74. Mörelius, E.; Nelson, N.; Theodorsson, E. Saliva collection using cotton buds with wooden sticks: A note of caution. Scand. J. Clin. Lab. Investig. 2006, 66, 15-18. [CrossRef] [PubMed]

(C) 2016 by the authors; licensee MDPI, Basel, Switzerland. This article is an open access article distributed under the terms and conditions of the Creative Commons by Attribution (CC-BY) license (http://creativecommons.org/licenses/by/4.0/). 